\title{
Health Should Not Be a Determinative Factor of Whether One Will be a Suitable Adoptive Parent
}

\author{
Brenda K. DeVries*
}

TABLE OF CONTENTS

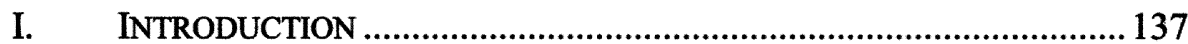

II. COURT DENIES OBESE COUPLE'S REQUEST TO ADOPT ..................140

III. THE ADOPTION SYSTEM IN THE UNITED STATES ..............................141

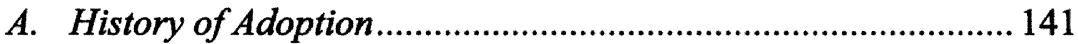

B. Current Standards for Adoption................................................... 142

C. Adoption Assistance and Child Welfare Act of 1980................. 143

D. Factors for Consideration in Adoption ...................................... 144

E. Defining What Makes a Parent a "Parent"............................... 146

IV. THE WEIGHT DEBATE: NATURE VS. NURTURE ................................. 149

A. Studies in Favor of Genetics ................................................. 150

B. Studies in Favor of Lifestyle Choices .........................................152

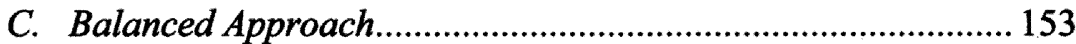

D. Overweight Versus Obesity ..................................................... 154

V. WEIGHT-BASED DISCRIMINATION CLAIMS ....................................155

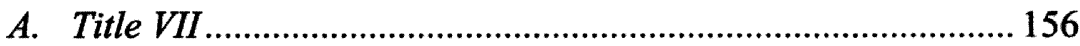



C. Equal Protection under the Fourteenth Amendment..................159

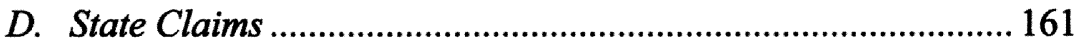

VI. COMPARING WEIGHT TO OTHER HEALTH CHOICES/



A. Comparing Weight to Smoking ............................................... 162

B. Comparing Weight to HIV and AIDS..................................... 165

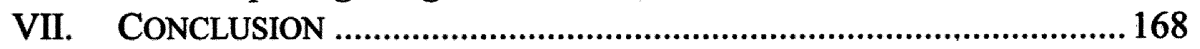

\section{INTRODUCTION}

I didn't want to be just another orphan, Mr. Warbucks. I wanted to believe I was special... I'm going to have a regular mother and father, like a regular kid. I am! ${ }^{1}$

* J.D. Candidate, 2008, Indiana University School of Law - Indianapolis; B.A., 2004, Calvin College.

1. ANNIE (Columbia Pictures Corporation 1982). 
The 1982 musical, Annie, tells the story of a fiery young orphan girl who finally catches a break when she is selected to spend a short time at the luxurious residence of wealthy industrialist, Oliver Warbucks. ${ }^{2}$ Viewers are captivated as Mr. Warbucks's heart is softened during the course of the film and he eventually adopts Annie to be his daughter.

Unfortunately, the majority of children are not as lucky as the fictitious red-headed Annie. The number of children waiting for the love, care, and stability of a permanent home is alarming. An enormous need for people to adopt children exists in the United States due to the overcrowding of the foster care system.

According to recent statistics, "[ $t]$ here are currently half a million children in foster care, with twenty percent of these children having remained there for

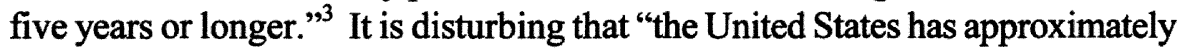
fourteen million children living at or below the poverty level, which is the highest child poverty rate among all industrialized nations." The high number of children living in poverty is a factor in the increase of the number of children placed in foster care. As the number of children in the foster care system increases, so do the caseloads of social workers, which limits "their ability to visit children, assess safety, and respond appropriately to the needs of the children and their families," which in turn contributes to longer stays in foster care. "Such a sequence of Catch-22s is clearly not in the best interest of children, their families, or the professionals charged with their oversight."6

Even though the number of children in foster care is on the rise, adoptions in the United States have decreased since the 1970s. Approximately 127,000 children are adopted every year in the United States, ${ }^{7}$ but this is "a sharp drop since the century-long high point of 175,000 adoptions in $1970 . " 8$ Some explanations for the decrease may be the smaller size of the average American family, the more frequent use of fertility treatments for childless couples, and the changing social attitudes towards single mothers. ${ }^{9}$ Growing numbers of recent adoptions have been international or transracial, creating families where the parents and children do not look alike. ${ }^{10}$ The attention attracted by these types

2. Id.

3. Deborah Paruch, The Orphaning of Underprivileged Children: America's Failed Child Welfare Law \& Policy, 8 J.L. \& FAM. STUD. 119, 144 (2006).

4. Id. at 119 .

5. Id. at 146 .

6. Id.

7. Child Welfare Information Gateway, Adoption, http://www.childwelfare.gov/adoption. (last visited March 12, 2009).

8. The Adoption History Project, http://www.uoregon.edu/ adoption/topics/adoption statistics.htm (last visited March 12, 2009).

9. The Evan B. Donaldson Adoption Institute, Private Domestic Adoption Facts, http://www.adoptioninstitute.org (last visited March 12, 2009).

10. The Adoption History Project, supra note 8. 
of adoptive families has led to the mistaken belief that the total number of adoptions is increasing. ${ }^{11}$

There is clearly an increasing need for adoptive families. Adoptions are preferential over keeping children in the foster care system because adoptions benefit and protect children in a myriad of ways. When a non-biological parent adopts a child, it formalizes a parental relationship between the adoptive parent and that child which shows the child that the parent is committed to him or her. Adoption guarantees that the child will be provided for financially and protects the inheritance rights of the child in case the adoptive parent dies without executing a will. ${ }^{12}$ It also secures other benefits for the child, such as health insurance and other employment-related benefits that may be available to the adoptive parent and to members of that parent's immediate family. ${ }^{13}$ In the event that the adoptive parent becomes unemployed, disabled, or dies, an adopted child will be eligible for Social Security and Worker's Compensation benefits. ${ }^{14}$ Adoption allows the parent to make decisions for the child in medical, educational, religious, and social settings. ${ }^{15}$ Adoption also creates legal standing for the adopted child to bring suits, such as a wrongful death action or next of kin claims. ${ }^{16}$

Given the rising need for adoptive families and the number of benefits that a child will receive after being adopted, it is surprising that any suitable prospective parents would be turned away and not permitted to adopt. Unfortunately, some parents attempting to adopt children are being turned away, supposedly due to their health characteristics, such as obesity. ${ }^{17}$ Due to the urgent need for adoptive parents, the health choices and characteristics of prospective adoptive parents should not be the determinative factor in whether they are deemed to be suitable adoptive parents.

Part II of this Note will detail the experience of an Independence, Missouri family after their adoption request was initially denied, allegedly due to their health characteristics. Part III will give a brief history of adoption, explain the current standards used for adoptions, and look at various factors used by agencies in determining whether prospective parents are eligible to adopt. The issue of whether weight is influenced more by genetics or individual lifestyle choices will be briefly addressed in Part IV, while Part V will explore the various methods of redress that may be pursued by persons facing discrimination based on their weight. Part V will also examine whether these remedies are available to prospective adoptive parents who are denied based on their health

11. Id.

12. Angela Dunne Tiritilli \& Susan Ann Koenig, Advocacy for Nebraska Children with Gay and Lesbian Parents: A Call for the Best Interests of the Child to be Paramount in the Case of Non-Biological, Non-Adoptive Parents, 36 CreIGHTON L. REv. 3, 8-9 (2002).

13. Id.

14. Id.

15. Id.

16. $I d$.

17. See infra Part II. 
choices or characteristics. Finally, Part VI will compare weight to other health choices and characteristics, such as smoking and HIV or AIDS. Ultimately, this Note will show that courts should not be able to use a couple's health choices or characteristics as the determinative factor when deciding whether that couple will be suitable adoptive parents.

\section{COURT DENIES OBESE COUPLE'S REQUEST TO ADOPT}

Gary and Cynthia Stocklaufer, a couple residing in Independence, Missouri, had taken in an infant from a cousin who was unable to raise him. ${ }^{18}$ The baby, Max, was one week old when he was placed with the Stocklaufer family and approximately one month later, the biological mother signed over parental rights to the Stocklaufers. ${ }^{19}$ After three months, the Stocklaufers desired to formally adopt Max. ${ }^{20}$ Even though the Stocklaufers were certified foster parents in Missouri, the family court judge did not grant the Stocklaufers' adoption request and removed baby Max from their home. ${ }^{21}$

Gary Stocklaufer believes that the court is discriminating against him due to his weight. ${ }^{22}$ At the time of the court's initial decision, Gary weighed approximately 550 pounds. ${ }^{23}$ Interestingly, the same judge approved the Stocklaufers' adoption of a son, Robert, in November $2000 .^{24}$ Gary was also considerably obese during the adoption of Robert and his weight has remained consistent since 2000 . $^{25}$

The court-appointed guardian stated that the court's decision to deny the adoption of Max was not based directly on Gary's weight, but on the health risks that Gary faces from obesity, such as diabetes or sleep apnea. ${ }^{26}$ The court has a duty to consider the best interests of the child in determining a permanent placement. ${ }^{27}$ Even though "[t]he amount of time, whether short or extended, spent with foster parents can have lasting effects on children,"

18. Jim Plink, Obese Foster Parent Upset Child Taken Away, KMBC-TV, http://www.kmbc.com/news/13763346/detail.html (last visited March 12, 2009).

19. Id.

20. Id.

21. Id.

22. $I d$.

23. Melissa Petri, Verdict: Too Fat to Adopt! The Parenting Weblog, Aug. 27, 2007, http://www.parenting-weblog.com/50226711/verdict_too_fat_to_adopt.php (last visited March 12, 2009).

24. Grant Slater, Man Has Gastric Surgery in Adoption Bid, USA TodAY, Aug. 24, 2007, available at $\mathrm{http}: / / \mathrm{www} . u s a t o d a y . c o m / n e w s / n a t i o n / 2007-08-24-2808744902$ x.htm (last visited March 12, 2009).

25. Id.

26. Laura Thornquist, Judge Says Man's Too Fat to Adopt, Fox News Channel 4 KANSAS CITY, July 25, 2007, available at http://www.fox4kc.com/wdafjudgesaysmanstoofattoad-4074406,0,7288347.story (last visited March 12, 2009).

27. Laura A. Turbe, Florida's Inconsistent Use of the Best Interests of the Child Standard, 33 STETSON L. REV. 369, 384 (2003).

28. Id. at 392. 
that it was best to remove Max from the only family he had ever known. ${ }^{29}$ The Stocklaufers plan to appeal the court's decision. ${ }^{30}$ Gary decided to undergo gastric bypass surgery in an attempt to lose weight and win the court's approval. ${ }^{31}$ After losing 250 pounds, Gary and his wife were finally granted custody of the baby more than a year after the whole ordeal began. ${ }^{32}$

Even though there is a happy ending to this story, it still does not diminish the fact that the Stocklaufers' adoption request was denied initially as a result of Gary's obesity. The courts did authorize the adoption after Gary lost the weight, ${ }^{33}$ which shows that there were not any other concerns with the Stocklaufers' ability to be suitable adoptive parents. Ultimately the court should not be able to use health characteristic, such as obesity, as the determinative factor when making decisions about whether to grant a petition for adoption.

\section{THE ADOPTION SYSTEM IN THE UNITED STATES}

\section{A. History of Adoption}

Historically, the primary purpose of adoption sought to ensure the continuity of the adopter's family. ${ }^{34}$ English common law did not include adoption; therefore, colonial America did not inherit a body of common law on adoption. $^{35}$ During the American Civil War, orphanages typically used indenture systems where children served as apprentices and were cared for by their masters. ${ }^{36}$ The indenture system evolved from one where children worked for food and shelter to the modern system of adoption where children become legal members of the adopter's family. ${ }^{37}$ In the modern system, adopted children are treated the same as biological children. ${ }^{38}$

Adoption law and practice is wholly statutory. ${ }^{39}$ "[A]doption exists purely as a privilege afforded by state statute. Each state creates its own law to govern this legal proceeding." "Parental rights and expectations involving adoption

29. Thornquist, supra note 26.

30. Plink, supra note 18.

31. Slater, supra note 24.

32. Monica Evans, Stocklaufter Loses 250 Pounds, Finally Abel to Adopt Son, Fox NEwS ChANNEl 4 KANSAS CITY, Sept. 14, 2008, available at http://www.fox4kc.com/wdafstocklauferloses250pounds-7429294,0,3693038.story (last visited March 12, 2009).

33. Id. (1991).

34. Joseph Evall, Sexual Orientation and Adoptive Matching, 25 FAM. L.Q. 347, 349

35. Id.

36. $I d$.

37. Id.

38. Id.

39. Jenny L. Plager, Note, Foster Parents and AIDS: Considering the Best Interests of a Foster Child in In Re Interest of John T., 4 Neb. Ct. App. 79, 538 N.W.2d 761 (1995), 77 NEB. L. REV. 617, 625-26 (1998).

40. Turbe, supra note 27 , at 372 . 
have historically been guarded by legislative enactment."41 Generally, modern adoption statutes are believed to date back to 1851 when the state of Massachusetts passed a statute that "required the written consent of the birth parents, the joint petition by both adoptive parents for the adoption, a judicial decree of adoption, and total severance, in law and practice, of the ties between the child and the birth parents."

There is absolutely no inherent right to adopt or to become a foster parent because the adoption process is a privilege based on state law. ${ }^{43}$ It is not guaranteed in any state or federal constitution. ${ }^{44}$ Adoption exists only where expressly granted by the law and is subject to restrictions and limitations imposed by that law. ${ }^{45}$ This makes it difficult to challenge a state's decision regarding adoption because there is no inherent right at stake. In addition, states are allowed to regulate the practice of adoption.

\section{B. Current Standards for Adoption}

States have the responsibility to carefully and safely place children with adoptive parents. Every state employs a "best interest of the child" standard to govern adoptions. ${ }^{46}$ Even though adoption laws vary among states, each statute will be construed liberally to ensure that the best interests of the child are served. 47 "Licensing rules, regulations, and standards all emphasize that the state's paramount duty is to the child rather than to prospective parents.",48 "[P]ublic and private agencies that place, investigate or supervise the placement of children with adults for foster care or adoption are under a clear legal duty to protect the best interests of children." 49

Even though a state's duty is to protect the child, an adoption always involves the weighing and balancing of many competing interests. The state must balance its own interests with those of the prospective parents in securing the welfare of the child. ${ }^{50}$ The overall well being of a child should always take precedence over other placement factors that states or adoption agencies may consider.

The "best interest of the child" standard has been criticized for being va-

41. Plager, supra note 39, at 626.

42. Evall, supra note 34, at 349 .

43. Plager, supra note 39 , at 626 .

44. Id.

45. Id.

46. W. Bradford Wilcox \& Robin Fretwell Wilson, Bringing Up Baby: Adoption, Marriage, and the Best Interests of the Child, 14 WM. \& MARY BILL RTS. J. 883, 885 (2006).

47. Turbe, supra note 27 , at 372.

48. Wilcox \& Wilson, supra note 46 , at 885 .

49. Lynn D. Wardle, Adult Sexuality, the Best Interests of Children, and Placement Liability of Foster-Care and Adoption Agencies, 6 J. L. \& FAM. STUD. 59,59 (2004). 1989)).

50. Plager, supra note 39, at 626 (citing Lindley v. Sullivan, 889 F.2d 124 (7th Cir. 
gue. 51 Indiana, like many other states, does not statutorily define its "best interest" standard. 52 Statutes in other states refer to "vague and imprecise factors, such as the physical, mental and emotional needs of the child" when attempting to determine the best interests of the child. ${ }^{53}$

It is possible that imprecise definitions for the "best interest" standard could result in discriminatory decisions by judges. Hillary Rodham Clinton wrote, "the 'best interests standard . . . is not properly a standard. Instead, it is a rationalization by decision-makers justifying their judgments about a child's future, like an empty vessel into which adult perceptions and prejudices are poured." "The failure of state statutes to specify factors that a court should consider in determining a child's 'best interest' promotes excessive, often discriminatory, removal of children and permits these decisions to be based on value judgments which may not be commonly held by society or legislatively approved." ${ }^{, 55}$ Appellate courts give great deference to trial courts and usually affirm the trial courts' decisions when hearing adoption appeals. ${ }^{56}$

\section{Adoption Assistance and Child Welfare Act of 1980}

The Adoption Assistance and Child Welfare Act ("Act") was passed in 1980 by Congress ${ }^{57}$ to correct or alleviate problems in the foster care system as well as to promote permanency. ${ }^{58}$ Although the purpose of the Act is to reunite the child with his or her family, if the child cannot be returned to the family, another resolution, such as adoption, should be pursued. When children are not able to live with their biological parents, a child welfare agency ensures that children receive proper care by implementing a case plan and case review requirements. 59

The Act requires the development of a case plan for each child under state supervision. ${ }^{60}$ This plan must be in writing and include at least the following information: "a description and a discussion of the appropriateness of the child's placement; a plan for assuring proper care of the child and appropriate

51. Andrea Charlow, Awarding Custody: The Best Interests of the Child and Other Fictions, 5 Yale L. \& Pol'y Rev. 267, 267-73 (1987) (criticizing the standard as overly vague and subject to abuse).

52. Paruch, supra note 3, at 153.

53. Id.

54. Martin Guggenheim, Reconsidering the Need for Counsel for Children in Custody, Visitation, and Child Protection Proceedings, 29 LOY. U. CHI. L. J. 299, 307 (1998) (quoting Hillary Clinton).

55. Paruch, supra note 3 , at 153.

56. Id.

57. See Adoption Assistance and Child Welfare Act of 1980, Pub. L. No. 96-272, 94 Stat. 500 (codified as amended in scattered sections of 42 U.S.C.) [hereinafter P.L. 96-272].

58. Abigail English, The HIV-AIDS Epidemic and the Child Welfare System: Protecting the Rights of Infants, Young Children, and Adolescents, 77 IowA L. REV. 1509, 1544 (1992).

59. Id. at 1543. See also P.L. 96-272.

60. Id. at 1544. See also P.L. 96-272. 
services for the child, parents, and foster parents; and the health and educational records of the child." ${ }^{\text {"61 }}$ The Act also requires that a case review system be implemented to ensure that a court or administrative agency evaluates each child's status at least every six months. ${ }^{62}$ Dispositional hearings to determine the future status of the child must be held within eighteen months from the date that child enters the system. ${ }^{63}$

\section{Factors for Consideration in Adoption}

During the adoption process, courts and agencies will consider a list of criteria to ascertain whether a couple will be suitable prospective parents for a child. ${ }^{64}$ There are several factors considered including: "age, religion, financial stability, emotional health, capacity for parenthood, physical health, marital status, infertility, adjustment to sterility, quality of the marital relationship, motives for adoption, attitudes toward nonmarital parenthood, the attitude of significant others, total personality, emotional maturity, and feelings about children." ${ }^{\circ 5}$ Where the couple lives and whether they have other children are also factors that agencies may consider when deciding among prospective adoptive families. ${ }^{66}$

Factors considered by adoption agencies have changed or evolved over time. At one time, agencies attempted to ensure that "every aspect of a prospective placement was ideal, which included the goal of matching a child to prospective parents in terms of physical appearance, intellectual capacity, and other factors." ${ }^{, 67}$ During that era, if the placement did not meet this ideal and exact standard, many agencies believed it was best to leave the child in the system pending a better match instead of placing him or her in an available home. ${ }^{68}$ The present goal of adoption is more general: "provide a permanent home that is suitable for the child and that is in his or her best interests." ${ }^{.69}$ This is evidenced by the fact that all states now employ the best interest of the child standard when evaluating prospective parents. ${ }^{70}$

Individual states may give some factors more consideration over other factors and may subject the factors to certain restrictions. For example, age restrictions on prospective adoptive parents are common in many states. "The

61. Id. See also P.L. 96-272.

62. Id. at 1545. See also P.L. 96-272.

63. Id. See also P.L. 96-272.

64. Cynthia R. Mabry, Lofton and the Future of Gay and Lesbian Adoption, 18 ST. THOMAS L. REV. 269, 289 (2005).

65. Evall, supra note 34 , at 350-51.

66. Wilcox \& Wilson, supra note 46 , at 886.

67. Id.

68. Id.

69. Turbe, supra note 27 , at 372 .

70. Paruch, supra note 3 , at 147.

71. Wilcox \& Wilson, supra note 46, at 886-87 (footnotes omitted). See, e.g., N.J. STAT. ANN. § 9:3-43 (West 2005) (setting a minimum age of eighteen and a ten year age difference 
provisions generally set a mandatory minimum age and may require a minimum age difference between the adoptive parent and child. Such provisions have, as a general rule, been held constitutional." 72 Other states focus primarily on the stability of the home. For instance, in the state of Florida, the home study of the child and prospective parents prior to the child's placement is designed "to select families who will be able to meet the physical, emotional, social, educational and financial needs of a child, while safeguarding the child from further loss and separation from primary caretakers." tues that allow "a child's wishes for adoption [to] be considered when the child is an older child."74

Some people contend that health status should be an important factor for courts and agencies to consider when the prospective parents' fitness is being evaluated. ${ }^{75}$ If one of the parents has a serious health condition that could lead to extra stress, financial concerns, familial disruptions, or even death, it could be argued that it is not in the child's best interest to be placed in that home. Placing a child permanently in a home can be a challenging transition without all of the extra disruptions that may accompany serious health situations.

One problem with having health status as a key factor, however, is the difficulty in determining the health of every prospective adoptive parent to a sufficient degree of certainty. Just because someone may be overweight, does not automatically mean that they are unhealthy and at risk for a wide array of illnesses. On the other hand, a prospective adoptive parent may appear completely healthy to an agency evaluator but actually have a serious medical condition that has not yet been discovered. It is not possible to know through an efficient administrative evaluation whether a prospective adoptive parent will face a serious health issue in the next month, year, or decade. Therefore, courts should not be allowed to place undue emphasis on this factor and deny adoption opportunities to prospective adoptive parents based on their health alone.

Other countries have placed certain restrictions on prospective adoptive parents based upon health conditions. South Korea and Taiwan both issued guidelines that require prospective parents to have a body mass index ("BMI") below $30 .^{76}$ China introduced a similar rule requiring prospective adoptive par-

requirement.); WASH. REV. CODE ANN. $§ 26.33 .140$ (West 2005).

72. Id.

73. Wilcox \& Wilson, supra note 46, at 891 (quoting FLA. ADMIN. CODE ANN. r. 65C$16.005(2)(2004))$.

74. Mabry, supra note 64, at 293.

75. See infra Part III E and discussion about Marriage of Carney v. Carney.

76. Hannah Davies, Love Goes to Waist - Couples Told To Shed the Kilos if They

Want To Adopt, SundaY MaIl (Australia), June 24, 2007, News, at 17; The Obesity Society, What is Obesity, http://www.obesity.org/information/what_is_obesity.asp (last visited March $12,2009)$. Obesity is defined with reference to BMI, which is a measure of body fat based on height-to-weight ratio that applies to adult men and women. Id. A BMI of 30 or greater is considered obese; a BMI between 25 and 29.9 is considered overweight. Id. BMI aside, as a rule of thumb, individuals who weigh $20 \%$ or more over their ideal body weight are considered obese; those who weigh either $100 \%$ or more, or are 100 pounds over their ideal weight, are termed "morbidly obese." Id. 
ents to have a BMI below $40 .{ }^{77}$ China also excludes "a wide variety of prospective parents, including people who are unmarried, obese or over [the age of] 50; people who have a facial deformity; and people who take antidepressants." 2005, Americans adopted 7,906 children from China. ${ }^{79}$ After China enacted the more restrictive regulations, the number of Chinese children adopted by Americans fell to 5,453 in $2007 .^{80}$ It will be interesting to see how those numbers will be impacted in coming years, given the increasing prevalence of obesity in the United States. ${ }^{81}$

More families are looking to adopt children from other countries outside of Asia for a variety of reasons, one of which may be restrictions on age, weight, and income requirements. "Of the more than 20,000 international adoptions in the [United States] last year, 732 of them were from Ethiopia, a 66 percent increase from $2005 .{ }^{, 82}$ With the high number of children waiting to be adopted domestically, one would hope that prospective adoptive parents would find the adoption process in the United States to be easier and more attractive than attempting to secure an international adoption.

The goal of adoption should be finding stable and permanent placements with loving families for all children. "[P]ermanent placement in a judicially approved home environment through the process of adoption is clearly preferable to confining the child to a life of transience, from one foster home to another . . . ."83 In order to place as many children as possible, no one group of prospective parents should ever be categorically excluded because of strict rules or regulations.

\section{E. Defining What Makes a Parent a "Parent"}

Even though the courts employ a best interest of the child standard and consider a variety of factors, it is important to address what characteristics actually define a parent as a "parent." The case of Marriage of Carney v. Carney involves a custody dispute between separated parents of two young boys. ${ }^{84}$ After the separation, the mother relinquished custody of the boys to their father. ${ }^{85}$ For reasons related to employment, the father moved to California with the boys

77. Davies, supra note 76 , at 17.

78. Marie Szaniszlo, Fat and Ugly Can't Adopt from China; New Regs Block WouldBe Parents, Boston Herald, Dec. 20, 2006, News, at 7.

79. AdoptiveFamilies.com, http://www.adoptivefamilies.com/china_adoption.php (last visited date March 12, 2009).

80. Id.

81. See discussion infra Sections IV and V for statistics regarding obesity.

82. Lisa Nicita, Ethiopian Adoptions on the Rise; Adopting from Africa; as Parents Embrace Multicultural Role and More Children Arrive, the Face of the Adoptive Family in the United States is Changing, ARIZONA REPUBLIC, Feb. 25, 2007, at 1.

83. Mabry, supra note 64, at 320 (citing language from State v. Summers, 311 N.E.2d 6, 13 (Ohio 1974)).

84. Marriage of Carney v. Carney, 598 P.2d 36 (Cal. 1979).

85. Id. at 37 . 
while the mother remained in New York. ${ }^{86}$ Three years later, while serving in the military reserve, the father was injured in a jeep accident, which left him "a quadriplegic ... with paralyzed legs and impaired use of his arms and hands." The following year, the mother moved for an order that would award her immediate custody of both boys. ${ }^{88}$ Even though she had not seen the children in nearly five years nor had made any contribution towards their support, the trial court ordered that the mother be allowed to move both children to New York. ${ }^{89}$ The father appealed, alleging that the trial court abused its discretion. ${ }^{90}$

The appellate judge ultimately reversed the trial court and permitted the father to retain custody of the children. ${ }^{91}$ The appellate court noted that the trial court gave great weight to the father's handicap and "its presumed adverse effect on his capacity to be a good father to the boys." 92 The trial court judge's ruling was "affected by serious misconceptions as to the importance of the involvement of parents in the purely physical aspects of their children's lives."93 The trial court judge appeared to be overly concerned that the father would not be able to participate with his sons in certain sporting or physical activities, which, in the judge's opinion, would not be a "normal relationship between father and boys." 94

The appellate court held that it is impermissible for a court to rely solely on a person's physical handicap as prima facie evidence of the person's unfitness as a parent, but that the court should consider several factors during its analysis. ${ }^{95}$ These factors include the parent's "actual and potential physical capabilities," 96 how the parent has adapted to the disability, how other family members have adjusted to the disability, and consider special contributions the disabled parent "may make to the family despite or even because of the handicap."97 This illustrates that the health or physical condition of a parent may be considered when determining what would best serve a child's best interests, but this factor "is ordinarily of minor importance." 98

The court also states what it believes lies at the heart of the parent-child relationship.

[The] essence [of parenting] lies in the ethical, emotional, and intellectual guidance the parent gives to the child

86. Id.

87. Id.

88. Id.

89. Id.

90. Carney, 598 P.2d at 36.

91. Id. at 45 .

92. Id. at 40.

93. Id. at 41 .

94. Id.

95. Id. at 42.

96. Carney, 598 P.2d at 42

97. Id.

98. Id. 
throughout his formative years, and often beyond. The source of this guidance is the adult's own experience of life; its motive power is parental love and concern for the child's well-being; and its teachings deal with such fundamental matters as the child's feelings about himself, his relationships with others, his system of values, his standards of conduct, and his goals and priorities in life. ${ }^{99}$

Later the court notes that a handicapped parent is a "whole person to the child who needs his affection, sympathy, and wisdom to deal with the problems of growing up." 100

The court's statements can also be applied to parents who are obese and are dealing with the physical limitations of obesity. Just because a parent, such as Gary Stocklaufer, is handicapped by obesity does not mean that he is unable to provide a stable and loving home where children are given the appropriate ethical, emotional, and intellectual guidance. According to the court, the health or physical condition of a parent can be considered but is typically of minor importance to the overall evaluation of the situation. ${ }^{101}$

Even if the parent with the disability is physically unable to care for the child, this is not sufficient to justify removing the child from that parent, according to the court in Carney. If the parent can still fulfill his or her functions as a parent with appropriate domestic assistance, the parent's disability should not be a determinative factor in regards to custody. There is no evidence that Gary Stocklaufer was physically unable to care for his potential son Max. In fact, Gary and his wife had adopted a son in 2000 and that placement appeared to be going smoothly. ${ }^{102}$ Even if his obesity did affect his ability to provide routine care for the child, this is not a sufficient reason to deny Gary Stocklaufer's adoption request, especially since Gary's spouse is not considered obese and he could employ someone to assist with Max's care.

The difference between the situation in Carney and the Stocklaufer family is that the father in Carney is the biological parent while Gary Stocklaufer is attempting to get the court's permission to adopt a child. Even though there is a legal distinction between biological and adoptive parents, the courts will still apply the best interests of the child standard in either situation. ${ }^{103}$ Therefore, courts should consider the list of factors from Carney when considering if a prospective adoptive parent's obesity will justify ruling that Gary Stocklaufer will not be a suitable adoptive parent.

A court established factor test to determine parental fitness raises the issue

99. Id. at 44 .

100. Id.

101. Id. at 42 .

102. See supra Section II.

103. Paruch, supra note 3 at 147. 
that the prospective adoptive parents have a much higher burden to meet than the biological parents in order to become a parent. The prospective adoptive parent must prove that he or she is a fit parent before getting permission from the state to adopt a child. ${ }^{104}$ States do not assess a biological parent's fitness before they are allowed to bear their own children or take their baby home from the hospital. States never make any determination if the biological parent is taking that child into a stable home environment where the child will be given ethical, emotional, and intellectual guidance or if that child will have the misfortune of winding up in the state's foster care system. Biological parents are only assessed in the event there is a problem at some point after the child is taken into an unstable environment; whereas prospective adoptive parents must go through a stringent assessment as part of their attempt to get a state's permission to adopt a child who desperately needs a loving home and committed parents.

\section{THE WEIGHT DEBATE: NATURE VS. NURTURE}

To determine how much emphasis courts can place on the health status factor when evaluating prospective adoptive parents, specifically with regards to weight, it is important to explore whether weight can actually be controlled by the individual or if genetics are ultimately responsible for the outcome. It is still not clear to what extent weight is influenced more by genetics or an individual's behavior and choices. No individual should be penalized for a characteristic that he or she is unable to control, as long as it will not interfere with his or her ability to be a supportive and loving parent.

"Despite all of the time, money and energy devoted to weight loss in this country, there remains a fair amount we still do not understand about how weight and obesity work." 105 The basic premise is deceptively simple and not controversial: "[i]f a person takes more calories in than $s /$ he expends, the excess calories are stored as fat and weight gain will result." ${ }^{106}$ Once we begin to apply this on an individual level, however, things get more complicated. There are individuals who can eat an exorbitant amount of food, do not exercise, but remain naturally thin. There are others who eat less, have a better diet and exercise on a regular basis, but are continuously battling weight gain. Other people become "morbidly obese at a young age and remain so all of their lives. This is part of the mystery that doctors and medical researchers are currently trying to understand." 107

104. Wilcox \& Wilson, supra note 46 , at 885

105. Elizabeth E. Theran, "Free to be Arbitrary and . . Capricious": Weight-Based Discrimination and the Logic of American Antidiscrimination Law, 11 CORNELL J.L. \& PUB. POL'Y 113, 148 (2001).

106. Id.

107. Id. at 149. 


\section{A. Studies in Favor of Genetics}

A person's weight may be more related to genetics than to personal health choices, despite what many people believe. After completing several studies, some of which are described in the following paragraphs, researchers at the University of Pennsylvania concluded that " 70 percent of the variation in peoples' weights may be accounted for by inheritance, a figure that means that weight is more strongly inherited than nearly any other condition, including mental illness, breast cancer or heart disease."108 That message is clearly contradictory to the popular conception of weight loss - all a person must do is eat less and exercise more. ${ }^{109}$ Dr. Jeffrey Friedman, an obesity researcher at the Rockefeller University, shared an analogy to illustrate the powerful biological controls over weight. He stated,

Those who doubt the power of basic drives, however, might note that although one can hold one's breath, this conscious act is soon overcome by the compulsion to breathe. The feeling of hunger is intense and, if not as potent as the drive to breathe, is probably no less powerful than the drive to drink when one is thirsty. This is the feeling the obese must resist after they have lost a significant amount of weight. ${ }^{110}$

Dr. Theodore VanItallie of Columbia University's College of Physicians and Surgeons notes that "[ $t]$ he results [of the studies] take obesity out of being a moral problem -- that obese people have a lack of willpower -- and put it more in the realm of metabolism," 111 further illustrating the importance of these findings.

Dr. Albert Stunkard of the University of Pennsylvania conducted multiple studies in an effort to learn more about the relationship between genetics and weight. $^{112}$ One study involved a Danish group of 540 adoptees whose average age was forty. ${ }^{113}$ Ninety percent of the children had been adopted during their first year of life. ${ }^{114}$ After comparing these adoptees to a registry with information regarding their biological parents, it turns out that the adoptees were very

108. Gina Kolata, Genes Take Charge, and Diets Fall by the Wayside, N.Y. TIMES, May 8 , 2007, at F1.

109. Id.

110. Id. (citing Trisha Gura, Tracing Leptin's Partners in Regulating Body Weight, SCIENCE, March 10, 2000).

111. Chubby? Blame Those Genes; Heredity Plays the Pivotal Role in Weight Control, TIME, June 4, 1990, at Health 80 [hereinafter Chubby?].

112. Kolata, supra note 108 , at F1.

113. Id.

114. $I d$. 
similar to their biological parents in terms of weight and obesity. ${ }^{115}$ No matter how fat or thin their adoptive parents were or what kind of lifestyle example was set, the weight of the adoptees reflected that of their biological parents. ${ }^{116}$ "Two of the major findings from this study were that there [is] a clear relation between the body-mass index of biologic parents and the weight class of adoptees, suggesting that genetic influences are important determinants of body fatness" 117 and that no relation exists "between the body-mass index of adoptive parents and the weight class of adoptees, suggesting that childhood family environment alone has little or no effect sic."118

A second study by Dr. Stunkard involved "93 pairs of identical twins who were reared apart, 154 pairs of identical twins who were reared together, 218 pairs of fraternal twins who were reared apart, and 208 pairs of fraternal twins who were reared together."119 This study showed that the identical twins had nearly identical BMIs, regardless of whether they had grown up separately or in the same home. ${ }^{120}$ "There was more variation in the [BMIs] of the fraternal twins, who, like any siblings, share some, but not all, genes."121 After this study, Dr. Stunkard concluded "if both biologic parents are fat, about $80 \%$ of their kids are going to be fat.", 22

Dr. Jules Hirsch, a research physician at Rockefeller University, and Dr. Rudolph L. Leibel, who is now working at Columbia University, conducted another study. ${ }^{123}$ They researched and observed people who had struggled with obesity since childhood or adolescence. ${ }^{124}$ These individuals resided at the Rockefeller University Hospital for eight months. ${ }^{125}$ Scientists were able to maintain strict control over the subjects' diets so the individuals could lose weight. $^{126}$ After the individuals were 100 pounds lighter than their initial weights, scientists examined their fat cells to see if the cells had shrunk or disappeared. $^{127}$ The fat cells had shrunk and were now normal in size so Dr. Hirsch assumed that the individuals participating in this study would all leave the hospital permanently thinner, but they all regained weight. ${ }^{128}$ One Rockefeller researcher explained, "[i]t is entirely possible that weight reduction, instead of resulting in a normal state for obese patients, results in an abnormal

115. Id.

116. Perspective, Open Forum. DenVER POST, July 1, 2007, at Perspective E-02.

117. Kolata, supra note 108 , at F1.

118. Id.

119. Id.

120. Id.

121. Id.

122. Chubby?, supra note 111, at Health 80.

123. Kolata, supra note 108 , at F1.

124. Id.

125. Id.

126. Id.

127. Id.

128. Id. 
state resembling that of starved nonobese individuals." 129

Despite these studies that indicate that weight is strongly influenced by genetics, people can still make efforts to control their weight. Dr. Stunkard said, "[t]he results did not mean that people are completely helpless to control their weight, . . . but . . . it did mean that those who tend to be fat will have to constantly battle their genetic inheritance if they want to reach and maintain a significantly lower weight." "130 Even though people may inherit a propensity to obesity, low-fat diets and exercise may potentially help to offset genetic tendencies. $^{131}$

\section{B. Studies in Favor of Lifestyle Choices}

On the other hand, there are studies and articles that indicate that weight can be managed or controlled by eating a healthy and balanced diet and exercising several times each week. A group of researchers from Northwestern University's Feinberg School of Medicine found that "a consistently high level of physical activity [starting] from young adulthood into middle age increases the odds of maintaining a stable weight." ${ }^{132}$ Maintaining a consistently high level of physical activity also decreases the amount of weight gained over time. ${ }^{133}$

This is one of the first studies to look at the relationship between physical activity and weight by examining several individuals' exercise patterns over a significant period of years. ${ }^{134}$ Data was collected from more than 2,600 individuals who were between the ages of 18 to 30 at the beginning of the study and studied for twenty years. ${ }^{135}$ Of the study participants, the ones who engaged in "at least thirty minutes of vigorous activity a day such as jogging, bicycling or swimming were more than twice as likely to maintain a stable BMI over the period of twenty years." 136 Even the highly active individuals who did gain weight, gained an average of fourteen pounds less over a period of twenty years than people with low levels of physical activity. ${ }^{137}$ Arlene Hankinson, an instructor at the Feinberg School of Medicine, stated, "[t]he results will hopefully encourage young people to become more active and to maintain high activity over a lifetime."138

The National Weight Control Registry ("NWCR") was founded in 1994

129. Kolata, supra note 108 , at F1.

130. Id.

131. Chubby?, supra note 111 , at Health 80.

132. Marla Paul, Breaking a Sweat Helps Control Weight Gain Over 20 Years, NORTHWESTERN UNIVERSITY NEWSCENTER, Nov. 13, 2007, http://www.northwestern.edu/ newscenter/stories/2007/11/cardia.html (last visited March 12, 2009).

133. Id.

134. Id.

135. Id.

136. Id.

137. Id.

138. Paul, supra note 132. 
by Rena Wing, Ph.D., from Brown Medical School, and James O. Hill, Ph.D., from the University of Colorado. ${ }^{139}$ The NCWR was established to "identify and investigate the characteristics of individuals who have succeeded at longterm weight loss" given the prevailing belief that few individuals actually succeed at keeping weight off for a long period of time. ${ }^{140}$ The NWCR is currently tracking more than 5,000 individuals who have been successful at losing at least thirty pounds and keeping the weight off for a minimum period of one year. $^{141}$

Eighty-nine percent of individuals reported changing diet and exercise habits in order to achieve their initial weight loss goals. ${ }^{142}$ Of those individuals who modified food and caloric intake, the common methods included restricting certain types of foods, limiting quantities, and counting calories. ${ }^{143}$ While the strategies to lose the initial weight varied among individuals, strategies to maintain the weight loss were similar. ${ }^{144}$ The strategies included eating a lowfat, low-calorie diet; frequent self-monitoring; and participating in regular physical activity. ${ }^{145}$ Nearly all of the individuals engaged in regular exercise equivalent to approximately one hour of brisk walking. ${ }^{146}$ Only a mere nine percent of participants used calorie reduction without regular physical activity. ${ }^{147}$ This study indicates that regular exercise and a healthy and balanced diet can be used to manage weight, even if the individual is genetically predisposed to being overweight.

\section{Balanced Approach}

The Centers for Disease Control and Prevention ("CDC") believes that body weight is the result of a variety of factors, including genes, metabolism, behavior, environment, culture, and socioeconomic status. ${ }^{148}$ No one factor will be determinative of whether an individual will struggle with obesity. The number of contributing factors makes obesity a complex health issue.

The CDC does, however, place more emphasis on the environmental factors that lead to obesity. According to the CDC, a main environmental factor contributing to obesity is urban sprawl, ${ }^{149}$ or "the uncontrolled, poorly planned,

139. The National Weight Control Registry, http://www.nwcr.ws/ (last visited March 12, 2009).

140. Id.

141. Id.

142. Id.

143. $I d$.

144. Id.

145. The National Weight Control Registry, supra note 139.

146. $I d$.

147. Id.

148. Ctrs. For Disease ConTrol \& PREvention, Overweight and Obesity: An Overview, http://www.cdc.gov/nccdphp/dnpa/obesity/contributing_factors.htm (last visited March 12, 2009).

149. Id. 
low-density, and single-use development, which expands from a metropolitan area." "150 Based on their environment or community, people may choose not to walk to the store or to work, which may be due to the absence of sidewalks. ${ }^{151}$ "Between 1977 and 1995, there was a thirty-seven percent decline in the use of pedestrian and bicycle travel partly due to the greater distances between residences and schools caused by sprawl." 152

The CDC also recognizes that even though science shows that genetics plays a role in obesity, genetics do not always predict future health accurately. ${ }^{153}$ Even though genetics may lead to an increased risk of weight gain, it ultimately depends on the person's individual behavior and choices. In some cases, genes and behavior are both important factors that contributes towards a person's obesity. ${ }^{154}$

\section{Overweight Versus Obesity}

Regardless of whether weight is inherited or a product of lifestyle and individual choice, it is important to recognize that not all overweight people are unhealthy. Just because an individual is overweight does not mean that he or she is automatically suffering from or at risk for health problems. "Not all fat people have the dread[ed] diseases associated with fat [n]or do all thin people escape those diseases. An association, moreover, is not causation. Patients' conditions should be treated, not their size."

It is very difficult to make a hard and fast rule regarding the overall health of an individual by only looking at one type of measurement or indicator. BMI measurements are not always a good indicator of health, even though some countries, such as South Korea, Taiwan, and China, have implemented restrictions on who is eligible to adopt based on BMI. ${ }^{156}$ Surgeon Douglas Nicholson, of Brisbane's Sunnybank Obesity Centre states, “[m] any people with a BMI of 30 are perfectly healthy and would make fabulous parents." ${ }^{, 157}$ Healthy individuals with a BMI of 30 would be rejected as prospective adoptive parents of children from South Korea and Taiwan, even though they may be healthy individuals. ${ }^{158}$

Courts should not overemphasize the health status factor and assume that an overweight individual will not be a suitable adoptive parent. There needs to

150. Graham M. Catlin, Comment, A More Palatable Solution? Comparing the Viability of Smart Growth Statutes to Other Legislative Methods of Controlling the Obesity Epidemic, 2007 WIS. L. REV. 1091, 1109 (2007).

151. CTRS. FOR Disease CONTROL \& PREVENTION, supra note 148.

152. Catlin, supra note 150 , at 1112.

153. CTRS. FOR DisEASE CONTROL \& PREVENTION, supra note 148.

154. Id.

155. Perspective, supra note 116.

156. Davies, supra note 76, at 17.

157. Id.

158. Id. 
be a distinction between being overweight or fat, which is a physical trait, and obesity, which is a health problem. As long as a person is healthy, their weight should not be a factor when the court is determining whether that person will be a suitable adoptive parent. The weight of a healthy person should not be considered more than height, hair color, or any other physical trait or characteristic.

\section{WEIGHT-BASED DISCRIMINATION CLAIMS}

Current medical studies estimate that at least thirty-four percent of American adults over twenty years old, or over 72 million people, meet the medical standard for obesity. ${ }^{159}$ Fifty-five percent of adult Americans, or 97 million, are categorized as either overweight or obese, and those numbers continue to rise. ${ }^{160}$ Considering that those estimates include the majority of adults in the United States, the risk of encountering weight-based discrimination is certainly heightened. ${ }^{161}$

If weight is proven to be the result of genetics rather than personal health choices and clearly beyond the control of some individuals, is it permissible to discriminate on this factor, especially in the situation of prospective adoptive parents? If so, being able to discriminate on the basis of weight "has the potential to affect every single American, fat, average-weight, or thin, because, as we shall see below, there is no 'minimum weight requirement' for discrimination 'too fat' is squarely in the eye of the beholder." 162 "Weight-based discrimination. . . [is] a non-traditional and non-explicit form of discrimination [but it] "can have a profound negative impact on members of the target group." 163

If a person has been discriminated against based on their weight he or she may bring a weight discrimination claim at the federal, state, or local level. ${ }^{164}$ Many of them choose to pursue multiple options. ${ }^{165}$ The likelihood of success depends on several factors, but overall, the probability of winning is fairly low, especially if the action is outside of a situation related to employment. ${ }^{166}$ No federal law directly prohibits discrimination against overweight or obese people. ${ }^{167}$ The person filing suit must do so under the protections of a general statute such as Title VII, the Americans with Disabilities Act of 1990, or the

159. Ctrs. For Disease CONTROL \& Prevention, Overweight and Obesity Trends Among Adults, http://www.cdc.gov/nchs/pressroom/07newsreleases/obesity.htm (last visited March 12, 2009).

160. Theran, supra note 105 , at 136.

161. Id.

162. Id.

163. Id. at 115 .

164. Id. at 173 .

165. Id.

166. Theran, supra note 105 , at 173.

167. Sayward Byrd, Comment, Civil Rights and the "Twinkie" Tax: The 900-Pound Gorilla in the War on Obesity, 65 LA. L. REV. 303, 342-43 (2004). 
Rehabilitations Act of $1973 .{ }^{168}$ Theoretically, the claimant can also bring a constitutional suit, but the chance of winning remains very low. ${ }^{169}$

\section{A. Title VII}

Title VII of the Civil Rights Act of 1964, codified as amended at 42 U.S.C. $\$ 2000 \mathrm{e}$, prohibits discrimination "against any individual with respect to his compensation, terms, conditions, or privileges of employment, because of such individual's race, color, religion, sex, or national origin." ${ }^{\text {170 }}$ As of 1991, Title VII recognizes both purposeful disparate treatment and facially neutral disparate impact claims. ${ }^{171}$ In the circumstance of weight, "those that succeed tend to be brought as disparate treatment, rather than disparate impact, claims." 172

Title VII specifically applies in the employment context, but does not apply directly to cases regarding prospective adoptive parents being denied due to their weight. Title VII may be applicable, however, if an obese couple was employed as foster parents and was later prohibited from fostering children as a result of their obesity, which may indicate disparate treatment. There is a debate whether foster parents are state employees or merely license holders, but it could be reasonably argued that foster parents are employed by the state. ${ }^{173}$

Once the claimant makes a prima facie case of disparate treatment, the employer has the opportunity to produce evidence of a nondiscriminatory reason for the different weight standards and must prove that the discriminatory standards can be justified as "bona fide occupational qualifications 'reasonably necessary to the normal operation of that particular business or enterprise' under 42 U.S.C. $\$ 2000 \mathrm{e}-2(\mathrm{e})$." "174 This is a fairly onerous burden for the employer to meet; therefore a Title VII plaintiff who establishes disparate treatment based on one of the protected categories is in a fairly strong position. The problem is that weight is not one of those categories and without such proof, Title VII affords the weight discrimination plaintiff very little relief or remedy. ${ }^{175}$

According to one author, "[c]ivil rights law in America is inordinately resistant to extending protection to the victims of 'new' forms of discrimination- 'new,' at least, in the sense that they are not already enshrined in our legal code,

168. Theran, supra note 105 , at 173.

169. Id.

170. 42 U.S.C. $\$ 2000 \mathrm{e}-2(\mathrm{a})(1)$ (1995).

171. Theran, supra note 105 , at 175.

172. Id.

173. Daniel Pollack, Negligence and Foster Children - Who is Responsible? CENTER FOR ADOPTION RESEARCH, Feb. 23, 2008, http://www.centerforadoptionresearch.org (discussing how various states classify foster parents for purposes of indemnification. For example, Illinois includes foster parents as employees of the state while other states, such as South Carolina, explicitly oppose the indemnification of foster parents as employees.) (last visited March 12, 2009).

174. Theran, supra note 105, at 176-77. See also 42 U.S.C. $§ 2000 \mathrm{e}-2$ (e) (1995).

175. Theran, supra note 105, at 177. 
even if they have been occurring for centuries."176 This is illustrative of the problem that the weight-based discrimination plaintiff faces. Discrimination on the basis of weight commonly occurs, but civil rights law in the United States does not yet provide any protection for this class of people.

\section{B. ADA and the Rehabilitation Act}

The ADA and the Rehabilitation Act apply primarily to employment discrimination based on disabilities, but "provide the framework and case law related to obesity litigation." "177 Under either the ADA or the Rehabilitation Act, a person establishes a claim of discrimination by proving that the plaintiff has a disability. ${ }^{178}$ The second way to establish a claim of discrimination is to prove that 'her employer believed she had an 'impairment' that, if it truly existed, would be covered under the statutes and that the employer discriminated against the plaintiff on that basis."

In order to establish a claim under either act, the plaintiff needs to show that obesity is a disability. ${ }^{180}$ "The medical diagnosis of an impairment is not as important in defining a disability under these acts as the effects of the impairment on a person's life." "I81 Under the Rehabilitation Act, a person has a disability when he or she "(i) has a physical or mental impairment which substantially limits one or more major life activities, (ii) has a record of such an impairment, or (iii) is regarded as having such an impairment."182 This definition is nearly identical to, and generally interchangeable with, the ADA definition. $^{183}$

Major life activities are considered "those basic activities that the average person in the general population can perform with little or no difficulty $[, \ldots$ including] caring for oneself, performing manual tasks, walking, seeing, hearing, speaking, breathing, learning, and working." 184 This list is not comprehensive, as the Equal Employment Opportunity Commission ("EEOC") also notes "other major life activities include, but are not limited to, sitting, standing, lifting, reaching.","185

As to the "substantially limits" language of the regulation, it is not enough to have a physical or mental impairment.

176. Id. at 114 .

177. Jessica Meyer, Article, Obesity Harassment in School: Simply "Teasing" Our Way to Unfettered Obesity Discrimination and Stripping Away the Right to Education, 23 LAW \& INEQ. 429,436 (2005).

178. Id.

179. Id.

180. Id.

181. Id. at 436-37.

182. 45 C.F.R. $\$ 84.3(j)(1)(2005)$.

183. See 42 U.S.C. $\S 12102(2)$ (2000).

184. Theran, supra note 105 , at 180.

185. Id. 
(1) The term substantially limits means: (i) Unable to perform a major life activity that the average person in the general population can perform; or (ii) Significantly restricted as to the condition, manner or duration under which an individual can perform a particular major life activity as compared to the condition, manner, or duration under which the average person in the general population can perform that same major life activity.

(2) The following factors should be considered in determining whether an individual is substantially limited in a major life activity: (i) The nature and severity of the impairment; (ii) The duration or expected duration of the impairment; and (iii) The permanent or long term impact, or the expected permanent or long term impact of or resulting from the impairment. ${ }^{186}$

Courts have interpreted the Rehabilitation Act broadly to include conditions such as substance abuse and alcoholism as disabilities. ${ }^{187}$ The Rehabilitation Act also "contains no language suggesting that its protection is linked to how an individual became impaired, or whether an individual contributed to his or her impairment, which is valuable in an obesity case where the cause and mutability of the condition may be at issue."

Although weight discrimination claims have been brought under the ADA and the Rehabilitation Act, the EEOC has found "obesity is a disability only in rare circumstances, noting its resemblance to physical, psychosocial, or cultural characteristics that are not impairments."189 A majority of courts have ruled that in the context of the ADA and the Rehabilitation Act, obesity does not qualify as a disability or a physical impairment except in special cases. ${ }^{190}$ Those courts have held obesity is not a disability without something more, such as a physiological impairment that affects weight control. ${ }^{191}$

186. 29 C.F.R. $\S 1630.2(j)(1)-(2)(1991)$.

187. See Teahan v. Metro-N. Commuter R.R. Co., 951 F.2d 511, 517 (2d Cir. 1991) (holding substance abuse is a handicap under the Rehabilitation Act); see also Gallagher v. Catto, 778 F. Supp. 570,577 (D.D.C. 1991) (holding alcoholism is a handicap under the Rehabilitation Act).

188. Meyer, supra note 177, at 437 (citing Cook v. R.I., Dep't of Mental Health, Retardation, and Hosps., 10 F.3d 17, 24 (1st Cir. 1993).

189. See 29 C.F.R. pt. 1630 App. $§ 1630.2$ (h) (2004) (“'[I]mpairment' does not include physical characteristics such as eye color, hair color, left-handedness, or height, weight or muscle tone that are within 'normal' range and are not the result of physiological disorder.").

190. Meyer, supra note 177 , at 440.

191. See Torcasio v. Murray, 57 F.3d 1340, 1354 (4th Cir. 1995) (reviewing case law finding obesity not covered by the ADA); see Whaley v. S.W. Student Transp., L.C., 2002 U.S. Dist. LEXIS 9103, 10 (D. Tex. 2002) (holding that obesity is not a disability because it is not a physical or mental impairment that substantially limits a major life activity); see Marc A. Koonin, Avoiding Claims of Discrimination Based on Personal Appearance, Grooming, and Hygiene Standards, 15 LAB. LAw. 19, 33-34 (1999) (noting that California, Pennsylvania, 
A few courts have ruled that obesity alone may constitute a handicap. Cook v. Rhode Island Department of Mental Health, Retardation, and Hospit$a l s^{192}$ was the first significant weight-discrimination case to reach the federal court of appeals. ${ }^{193}$ The First Circuit held it was inappropriate under the Rehabilitation Act for an employer to discriminate based on a prospective employee's morbid obesity. ${ }^{194}$ The court did not hold that morbid obesity itself constituted a disability. Rather, the court held that because the jury could reasonably conclude that the employer perceived that obesity impaired the plaintiff's life by limiting mobility and had subsequently refused her employment, the perceived disability prong of the Rehabilitation Act was satisfied. ${ }^{195}$

Other courts have adopted positions that are inconsistent with Cook $v$. Rhode Island. The "Second and Sixth Circuits have both held that obesity, standing alone, cannot constitute a disabling impairment without some further underlying physiological disorder." "This shows that the ADA should be available for a person who is "obese enough to require accommodation or who is actually sufficiently impaired to fall within the statutory definition of disability. However, for those who suffer weight-based discrimination at lower levels of obesity or impairment, the ADA does not, cannot, and probably should not provide a sufficient remedy."197

\section{Equal Protection under the Fourteenth Amendment}

Not allowing obese individuals to adopt due to factors beyond their control could implicate the Equal Protection Clause of the Fourteenth Amendment because such a regulatory constraint would disproportionately impact the obese. ${ }^{198}$ In order to succeed on an equal protection claim, a plaintiff would need to show both that the burden of an imposed regulation - such as evaluating prospective parents based on their weight - falls disproportionately on obese individuals, ${ }^{199}$ and that the lawmakers intended that disproportionate impact. ${ }^{200}$ Alternatively, the plaintiff would have to show that the obesity regulation deprives him or her of a fundamental right or that it creates a suspect class of obese individuals. ${ }^{201}$

If a plaintiff could make a prima facie showing of either of these alterna-

Missouri, North Dakota, and New York courts have ruled that obesity alone is not a disability).

192. Cook v. R.I. Dep't of Mental Health, Retardation, and Hosps., 10 F.3d 17 (1st Cir. 1993).

193. Theran, supra note 105 , at 183.

194. Cook, 10 F.3d at 28.

195. Id. at 23.

196. Theran, supra note 105 , at 184 . See Francis v. City of Meriden, 129 F.3d 281, 286

(2d Cir. 1997); Andrews v. Ohio, 104 F.3d 803, 810 (6th Cir. 1997).

197. Theran, supra note 105 , at 189 (footnote omitted).

198. See U.S. ConsT. amend. XIV, $\S 1$.

199. See generally Washington v. Davis, 426 U.S. 229, 239-41 (1976) (discussing the dual requirements of disproportionate impact and discriminatory legislative intent).

200. Id.

201. Theran, supra note 105, at 174. 
tives, the regulation would warrant the strictest standard of review. ${ }^{202}$ Under strict scrutiny, the regulation would be constitutional if a court determines that the regulation is necessary to accomplish a compelling state goal. ${ }^{203}$ As shown earlier, however, adoption is a privilege afforded by statute and is not a fundamental right; ${ }^{204}$ strict scrutiny would therefore not be warranted. Also, obese individuals have not been identified as a suspect class, and such regulations would thus not garner strict scrutiny. ${ }^{205}$

The state action requirement of the Fourteenth Amendment means that such suits could only be sustained against either governmental or quasigovernmental entities. ${ }^{206}$ Purely private conduct does not fall underneath the Fourteenth Amendment. ${ }^{207}$ In the case of the prospective adoptive parents, a court's denial of an adoption satisfies the state action requirement. "Even when the defendant is a state actor, under the Fourteenth Amendment, discriminatory policies that do not deprive someone of a fundamental right, create a suspect or quasi-suspect classification, or operate to disadvantage a suspect or quasisuspect class only receive the mildest standard of review: rational basis review."208

Under rational basis review, courts generally uphold as constitutional any regulation that is rationally related to a legitimate government interest or public purpose. $^{209}$ Rational basis review is a "sliding scale, dependent upon whether the class affected is a protected class and whether the interest advanced by the state is a legitimate one." 210

Because weight or appearance is not a suspect...classification, under the current state of the doctrine the discriminatory policy would merely have to be conceivably rationally related to a legitimate governmental interest in order to pass constitutional muster--a test that, in practice, almost always amounts to little more than a rubber stamp. ${ }^{211}$

The Government may support the prevention of adoption by obese people by asserting that obesity plays a significant role in chronic diseases. Since one purpose of government is to promote the safety and welfare of its citizens, ${ }^{212}$ it

202. Id.

203. Id.

204. Turbe, supra note 27 at 372 .

205. Theran, supra note 105 , at 174.

206. Id.

207. Id.

208. Id.

209. Id.

210. Byrd, supra note 167 , at 344 .

211. Theran, supra note 105 , at 174.

212. See U.S. ConsT. amend. X. 
might impede this legitimate interest to permanently place a child in a home where one of the parents is at a heightened risk for severe health complications or possibly death. The state agency could rationally assert that such a placement would not be the best for the adopted child's welfare.

Opponents to the policy or practice of denying prospective adoptive parents based on their weight could assert that obesity is an individual, not a public, problem. Government regulation in this area infringes on individual freedoms and personal responsibility. A person's weight does not indicate whether they will be a suitable parent. ${ }^{213}$ In addition, weight is not always an accurate indicator of health. ${ }^{214}$ It is not possible to assess an individual's overall health by looking at only at the person's weight. ${ }^{215}$

Despite the contentions of the opposition, it is likely that a court would find that a legitimate state interest is advanced by agencies placing children only with parents who are deemed to be "healthy." Medical studies have proven a link between obesity and heightened health risks, including premature death. ${ }^{216}$ Therefore, it is rational for the state to want to ensure that the adoptive parents will be able to raise and care for the adopted children into the future; thus preventing the children from later becoming wards of the state.

\section{State Claims}

At the state level, the situation is often not much better for the weightbased discrimination plaintiff. Michigan is the only state, along with the District of Columbia, that has antidiscrimination statutes that directly address weight-based discrimination. ${ }^{217}$ "[I]n all other states, weight-discrimination plaintiffs must bring suit under the state constitution or state human rights or public accommodations laws."218

Michigan's statute, the Elliott-Larsen Civil Rights Act (“Act"), ${ }^{219}$ applies to weight-based discrimination within the contexts of contracts and employment. ${ }^{20}$ The Act has "more lenient standards than the ADA or the Rehabilitation Act in that a plaintiff does not have to prove that illegitimate criteria, such as weight or size, were the sole reasons or even the main reason for the termination."221 The defendant has greater responsibility because the defendant has the

213. See supra Part II Section E.

214. See supra Part IV Section D.

215. Id.

216. Kenneth F. Adams et al., Overweight, Obesity, and Mortality in an Large Prospective Cohort of Persons 50 to 71 Years Old, 355 N ENGL. J. MED. 763, (2006).

217. Theran, supra note 105 , at 173 . Michigan's civil rights law includes height and weight as prohibited forms of discrimination. MiCH. CoMP. LAWs $\S 37.2102$ (West 2001). The District of Columbia added personal appearance and sexual orientation to its list of discriminatory factors. D.C. CoDE $\S 2-1401.01$ (2007).

218. Theran, supra note 105, at 173 (footnote omitted).

219. Мich. CoMP. LAWs ANN. $\S \S 37.2101-37.2804$ (West 2001 \& Supp. 2008).

220. Id.

221. Meyer, supra note 177, at 444. 
burden to state a non-discriminatory reason for its action once the plaintiff lays out a prima facie case of discrimination based on size. "A plaintiff can establish a prima facie case by showing that "(1) she is a member of a statutorily protected class; (2) that she was qualified for the job; (3) that she was discharged from the job; and (4) that she was replaced by someone outside the protected group." "223 This statute is significant because it exemplifies the possibility of developing and passing legislation that protects obese individuals from unjust discrimination.

\section{COMPARING WEIGHT TO OTHER HEALTH CHOICES/CHARACTERISTICS}

If courts are permitted to apply the best interests of the child standard to a prospective adoptive parent's weight-which is a health characteristic and arguably a health choice-it would be interesting to compare how courts have treated parents who (1) have a certain deleterious health characteristic, such as HIV or AIDS, or (2) have made other health choices, such as choosing to smoke. If courts are truly concerned about the best interests of the child, no child should be placed in any environment where the adoptive parent is at risk due to a health choice or characteristic, regardless of whether that risk is voluntarily assumed or acquired.

\section{A. Comparing Weight to Smoking}

It is unreasonable to dispute that smoking is bad for a person's health. Smoking can exacerbate or lead to several diseases, including chronic obstructive pulmonary disease, lung cancer, osteoporosis, and periodontal disease, just to list a few. ${ }^{224}$ It is also commonly known that parents who smoke expose their children to the risks of secondhand smoke. Exposing children to secondhand smoke can cause respiratory problems, ear infections, more frequent and severe asthma attacks, and puts infants at risk for sudden infant death syndrome ("SIDS"). ${ }^{225}$ Researchers from the Department of Pediatrics at the University of Wisconsin Medical School reported that "[a]t least 6,200 children die each year in the United States because of their parents' smoking, killed by such things as lung infections and burns."226 According to the Surgeon General of

222. Id.

223. Id. at 445 (quoting Penzato v. Cont'l Cablevision of Mich., Inc., 1996 Mich. App. LEXIS 1067, at *4 (Mich. Ct. App. 1996)).

224. See American Council on Science and Health, The Scoop on Smoking, Health Effects, http://thescooponsmoking.org/xhtml/effectsHome.php (last visited March 12, 2009).

225. U.S. Dept. of Health and Human Services, The Health Consequences of INVOLUNTARY EXPOSURE TO TOBACCO SMOKE: A REPORT OF THE SURGEON GENERAL, U.S. DEPARTMENT OF HEALTH AND HUMAN SERVICES (2006), available at http://www.surgeon general.gov/library/secondhandsmoke/factsheets/factsheet2.html (last visited March 12, 2009).

226. Guggenheim, supra note 54, at 316. Parents Warned on Smoking, N.Y. TIMES, July 15, 1997, at C2 (citing C. Andrew Aligne, MD \& Jeffrey J. Stoddard, MD, Tobacco and 
the U.S. Department of Health and Human Services, "there is no risk-free level of secondhand smoke exposure" and even short periods of exposure can be dangerous. ${ }^{227}$

In 1993, the America Bar Association ("ABA") committee drafted a resolution that aimed to protect children from the many risks and dangers associated with exposure to secondhand smoke. ${ }^{228}$ One of the ABA committee's recommendations was to "make parental smoking habits a factor to be considered in custody determinations." 229 The ABA committee also proposed mandating states to consider the smoking habits of prospective adoptive families as part of their placement decision. ${ }^{230}$

Although it is not mandatory, courts are beginning to apply the best interest of the child standard to determine whether a child should be placed in a home where a parent smokes. ${ }^{231}$ Parental smoking is one factor that the courts consider when applying the best interests of the child standard. Courts may even place more weight on parental smoking habits when a child has existing health problems that could be exacerbated by exposure to secondhand smoke. . $^{232}$

There are several child custody cases that show how some courts are choosing to address parental smoking. For example, in Unger v. Unger, ${ }^{233}$ the court held that "the fact that a parent smokes cigarettes is a permissible parental habit to consider when determining what is in the best interests of the children because it may affect their health and safety." re Julie Anne, ${ }^{235}$ described secondhand smoke as a "real and substantial danger" ${ }^{236}$ because it can cause and exacerbate illnesses, especially in children. This "danger is both a relevant factor and physical health factor that a family court is mandated to consider under the statute."237 Trial courts do not abuse its discretion in protecting the children from being exposed to secondhand smoke. ${ }^{238}$

Similarly, the focus of the court in Lizzio v. Lizzio was on secondhand cigarette smoke. ${ }^{239}$ That court went on to opine that "we are at a point in time when... a parent or guardian could be prosecuted successfully for neglecting his or her child as a result of subjecting the infant to an atmosphere contaminated

Children: An Economic Evaluation of the Medical Effects of Parental Smoking, 1997

ARCHIVES OF PEDIATRICS \& ADOLESCENT MED. 643, 651 tbl. 2).

227. U.S. DEPT. OF HEALTH AND HUMAN SERVS., supra note 225.

228. Guggenheim, supra note 54, at 316.

229. Id.

230. Id.

231. Cori S. Annapolen, Maternal Smoking During Pregnancy: Legal Responses to the

Public Health Crisis, 12 VA. J. Soc. PoL'Y \& L. 744, 756 (2005)

232. Id.

233. Unger v. Unger, 274 N.J. Super. 532 (1994).

234. ai. at 538.

235. In re Julie Anne, 121 Ohio Misc.2nd 20 (2002), 780 N.E.2d 635 (2002).

236. Id.

237. Id.

238. Day v. Day, 2005 Ohio 4343, (2005).

239. Lizzio v. Lizzio, 162 Misc. 2 d 701 (N.Y. 1994). 
with health-destructive tobacco smoke."240 This judge classifies cigarette smoke much more seriously than the majority of family law judges, but it does indicate that some judges are beginning to consider secondhand smoke as an important health factor in custody cases, especially when a child has been diagnosed with a respiratory condition, such as asthma. ${ }^{241}$

Other courts are applying battery jurisprudence ${ }^{242}$ to secondhand smoke, which shows that courts consider smoking to be harmful contact in other situations outside of the realm of custody battles. ${ }^{243}$ In Leichtman v. WLW Jacor Communications, Inc., an anti-smoking advocate was scheduled to appear on a radio talk show to talk about the dangers of smoking and secondhand smoke. ${ }^{244}$ During his time in the studio, the host lit a cigar and blew smoke in the advocate's face several times. ${ }^{245}$ The advocate sued the host for damages, claiming that the host's intentional act qualified as a battery and the court ruled in the advocate's favor. ${ }^{246}$

Even though it is well established that exposure to secondhand smoke is harmful - thousands of children are put at risk and die from secondhand smoke every year ${ }^{247}$-there have been no publicized accounts of prospective adoptive parents not being permitted to adopt because they choose to smoke. Is living with a parent who smokes, biological or adoptive, truly in the best interests of the child? If courts and judges are going to put more emphasis on the health factor, then smoking needs to be given at least, if not more, consideration as a factor than weight for the following four reasons. First, obesity poses less risk to the child than being exposed to secondhand smoke. There is a conscious individual choice with smoking, as opposed to becoming obese, which may be influenced by genetics. In addition, exposing a child to secondhand smoke could give rise to a battery action against the parent, where there is no such risk with obesity. Lastly, smoking is not essential to surviving, but one must eat in order to live.

First, obesity does not pose the same threat to other individuals like the negative effects of smoking. ${ }^{248}$ The effects of secondhand smoke on other individuals living in the same house pose more of a risk and have more serious effects than having a parent who may be obese or overweight. Although both lifestyles are unhealthy and pose risks to the individual who is choosing to smoke or who is overweight, only smoking directly impacts those living in the

240. Id. at 705 .

241. Id. at 705-06.

242. Elements of battery: (a) the defendant acted with the intent to cause a harmful or offensive contact, and that (b) the contact actually occurred. Leichtman v. WLW Jacor Communications, Inc. 634 N.E.2d 697, 698 (Ohio Ct. App. 1994).

243. Id.

244. Id. 698.

245. Id.

246. Id.

247. Guggenheim, supra note 54, at 316.

248. Catlin, supra note 150, at 1096-97. 
same house in a negative way on a daily basis. Having a parent who is obese may be inconvenient at times, but obesity alone is not a direct threat to the wellbeing and health of the children. ${ }^{249}$

Second, an individual makes a conscious choice to begin smoking while there is scientific evidence that shows that weight may be caused or greatly influenced by genetics. Once an individual chooses to smoke, it can become an addiction, but the individual makes the initial decision on whether to pick up the cigarette. A person struggling with obesity has often been dealing with weight issues since childhood and did not really make the choice to become obese. There are a variety of diets and treatments available to help overweight individuals to lose weight, if they choose. The original choice to become overweight, however, is often not a conscious one made by the obese person.

Third, according to the court in Leichtman, blowing smoke in the face of another person may constitute battery, ${ }^{250}$ which could feasibly extend to biological or adoptive parents who expose their children to secondhand smoke. Putting children in a home where they may be "battered" is definitely not in their best interests. Obesity has not been subject to the same battery analysis as smoking. Children placed in a home with an obese parent are not at risk of being "battered" in the same way as someone living in the home where one or more of the parents choose to smoke.

Lastly, smoking is not a necessity, whereas eating is essential to survival. A person who is addicted to nicotine may feel very compelled to smoke due to the addition, but it is not an absolute necessity for life. All people, even those who are overweight, must eat a certain amount of food to live.

Ultimately, if courts are going to consider the health choices and characteristics of prospective adoptive parents, more emphasis should be placed on other negative health choices, such as smoking. Choosing to smoke is a proven and serious risk to others, is entirely by choice, and is not necessary in order to live. Courts should not be able to single out one health characteristic, such as weight, when making their determination, especially when they are not emphasizing other choices that pose much more serious risks to the child.

\section{B. Comparing Weight to HIV and AIDS}

Unlike smoking, coping with HIV or AIDS is not a choice because there is currently no cure once it is contracted. Courts are not consistent in their decisions regarding parents and prospective adoptive parents who have HIV or AIDS. ${ }^{251}$

John Tv. Carraher ${ }^{252}$ is one of the first cases that dealt with an attempt to remove a foster child from the foster parents who desired to adopt him because

249. See supra Part IV, Section D.

250. Leichtman, 634 N.E.2d at 698-99.

251. See supra Part V Section B.

252. John T. v. Carraher, 538 N.W.2d 761 (Neb. Ct.App. 1995). 
the foster mother was infected with AIDS. ${ }^{253}$ The child was three and a half years old and had been placed with the foster parents as part of a "fos-adopt" placement, meaning that the placement was assumed to be permanent with an adoption to occur at some point in the future. ${ }^{254}$ When the foster parents applied to be "fos-adopt" parents, they were aware that the mother was HIV positive but did not disclose that fact to the Department of Social Services (DSS). ${ }^{255}$ After DSS became aware that the foster mother was infected with HIV, DSS requested a change in placement for John. ${ }^{256}$ When questioned as to the reasons for the change in placement, a DSS spokesperson responded that it would be difficult for John to lose his adoptive mother at a young age. ${ }^{257}$ The foster parents sued the state, alleging a violation of the Rehabilitation Act by excluding the mother from participating in the state's foster care and adoption programs based on her HIV status. ${ }^{258}$ Eventually the court allowed the foster couple to adopt the child, but sadly, the foster mother died from AIDS one month before the adoption was finalized. ${ }^{259}$

McNicholas v. Johnson ${ }^{260}$ is another case where the parents wishing to adopt a child have been diagnosed with HIV. ${ }^{261}$ In that case, Johnson chose relatives, Mr. and Mrs. McNicholas, to be the adoptive parents of her baby girl and they agreed to become the girl's parents. ${ }^{262}$ The Department of Public Welfare prepared an Adoption Summary report as part of the adoption process and disclosed that Mr. and Mrs. McNicholas were infected with HIV and were expected to develop AIDS within the next year or two; therefore, they would be unable to care for the child. ${ }^{263}$ The McNicolases also suffered from other phyiscial ailments. ${ }^{264} \mathrm{Mr}$. McNicholas had been diagnosed with encephalitis, was on medication to help him sleep, and used an inhaler to prevent him from contracting pneumonia. ${ }^{265}$ Mrs. McNicholas had contracted a Non-Hodgkins Lymphoma and undergone chemotherapy. ${ }^{266}$

Johnson wrote a letter to the court expressing her concerns about the prospective adoption and requested that the court not permit Mr. and Mrs. McNicholas to adopt her biological child. ${ }^{267}$ In order for a biological mother to withdraw her consent to an adoption, she has the burden of establishing that she

253. Id. at 762 .

254. Id. at 765 .

255. Id.

256. Id. at 766 .

257. Id.

258. Doe v. Nebraska, 345 F.3d 593 (2003).

259. Plager, supra note 39, at 623.

260. McNicholas v. Johnson, 612 N.E.2d 569 (Ind. Ct. App. 1993).

261. Id.

262. Id. at $570-571$.

263. Id. at 571 .

264. Id.

265. Id.

266. McNicholas, 612 N.E.2d at 571 .

267. Id. 
is acting in the best interest of the child. ${ }^{268}$ In this case, the court allowed Johnson to withdraw her consent because it was not in the child's best interest to be orphaned at a later date. ${ }^{269}$

There are several problems with the court's decision in McNicholas v. Johnson. First, the court did not take any evidence from Mr. and Mrs. McNicholas or from their doctor about their ability to care for the child. ${ }^{270}$ There is a complete lack of credible medical evidence about the nature of HIV and AIDS, the various available treatments, the present health condition of $\mathrm{Mr}$. and Mrs. McNicholas, or their future prognosis. ${ }^{271}$ Second, the court assumes that if the couple develops AIDS, they will be unable to care for the child, despite evidence that there was a strong family support system and a much older son of the couple that would be able to care for the child. ${ }^{272}$

Currently, it is widely accepted that a prospective adoptive parent with HIV or AIDS will not pose a transmission risk to the child, but is a court still going to consider HIV or AIDS as a significant factor during the best interest of the child analysis? If courts and judges are going to emphasize the health of the prospective parents as a factor, then HIV and AIDS need to be given at least the same consideration as weight as a factor for the following reasons.

First, although there are several medications that prolong life or extend the period before HIV develops into AIDS and treatments are becoming more advanced, there is no cure for AIDS. ${ }^{273}$ Highly active antiretroviral therapy ("HAART") is a combination therapy of Azidothymidine ("AZT"), nonnucleoside reverse transcriptase inhibitors, and protease inhibitors. ${ }^{274}$ As HAART treatments become more commonly prescribed, AIDS-related deaths have been significantly reduced. ${ }^{275}$ While there are various treatments for obesity, including surgery and lifestyle changes, the amount of success varies from person to person. $^{276}$

Second, it is not possible to predict how long a person with AIDS has to live, just like it is also not possible to accurately predict the number of years that an obese person has to live. Advanced drug therapies have extended the life of persons with AIDS to the point where some people call it a chronic disease. ${ }^{277}$ Likewise, an obese person may live for decades, although premature

268. Id. at 573 .

269. Id.

270. Id. at 578 (Sharpnack, J., dissenting).

271. Id. at 573.

272. McNicholas, 612 N.E.2d at 575 ..

273. AIDS.ORG, Fact Sheets: Background Information. 101: What is AIDS?, http:// www.aids.org/factSheets/101-What-is-AIDS.html (last visited March 12, 2009).

274. Jody Marcucci, Doe v. County of Centre: Foster Children, AIDS, The Americans with Disabilities Act, and the Direct Threat Exception, 52 DEPAUL L. REV. 945, 949 (2003).

275. Id.

276. WEB MD, Healthy Eating \& Diet: Obesity - Treatment Overview, http://www. webmd.com/diet/tc/obesity-treatment-overview (last visited March 12, 2009).

277. AIDS.ORG, Frequently Asked Questions, http://www.aids.org/info/do-drugs-cureaids.html (last visited March 12, 2009). 
death is one of the health risks associated with the health condition. ${ }^{278}$

Third, unlike smoking, people do not choose to contract HIV or to become obese. Most people are not aware of the precise moment when they contract HIV and may not find out until years later when symptoms begin to appear. ${ }^{279}$ Scientific studies show that weight is highly influenced by genetics and the environment and may not be a real choice for some people. ${ }^{280}$

Fourth, the risk of transmission of HIV between members of the same household is low. ${ }^{281}$ Dr. Morin, a specialist in infectious diseases who treats HIV and AIDS patients, testified in John T. v. Carraher that transmission to household members who are not sexual partners is a risk which is "miniscule, at best." 282 Likewise, even though weight may have a genetic component, there is not a risk of transmitting the "obesity" gene from an adoptive parent to his or her adopted child.

Lastly, HIV and AIDS are considered disabilities and are protected statuses under the ADA; ${ }^{283}$ therefore, people with HIV or AIDS cannot be discriminated against. ${ }^{284}$ Since both are protected statuses, courts would not be permitted to use either health characteristic as a determinative factor in whether a prospective adoptive parent with HIV or AIDS would be allowed to adopt. On the other hand, weight is not a protected status, and it is possible for courts to deny prospective adoptive parents on this basis alone. ${ }^{285}$

For the reasons explored above, the issue of weight is more similar to HIV or AIDS than smoking. A parent who is obese or infected with HIV or AIDS poses little risk to a child as opposed to a parent who exposes a child to secondhand smoke. Being obese or infected with HIV will not give rise to a battery action, unlike being exposed to secondhand smoke. Smoking tends to be a conscious, individual choice, but few people choose to become obese or infected with HIV. Courts are not allowed to use HIV or AIDS as a determinative factor in whether a prospective adoptive couple will be permitted to adopt and should evaluate an obese adoptive couple under a similar framework.

\section{CONCLUSION}

In conclusion, each child deserves a permanent home and the love and support that committed parents can provide. Courts should evaluate all pros-

278. WEB MD, supra note 276.

279. AIDS.ORG, supra note 277.

280. See supra Part IV Section A.

281. AIDS.ORG, supra note 277.

282. John T. v. Carraher, 538 N.W.2d 761, 765 (Neb. Ct.App. 1995).

283. A person qualifies as an "individual with a disability" if she can show that she either (1) has a "physical or mental impairment that substantially limits one or more major life activities," (2) has a "record of" such an impairment, or (3) is "regarded as having such an impairment." 42 U.S.C. $\$ 12102$ (2000).

284. Marcucci, supra note 274.

285. See supra Part V. 
pective adoptive parents based upon their individual character and ability to parent, not merely on their physical characteristics and limitations, such as weight. In the end, what defines a parent as a parent is their ability to provide ethical, emotional, and intellectual guidance to that child and not whether the parent is dealing with a particular health characteristic, such as obesity.

"All states should adopt the Child Welfare League of America's standard against discrimination as a practice in adoption proceedings and investigations" ${ }^{\mathbf{2 8 6}}$ in an effort to work towards a nondiscriminatory evaluation process. "According to the Child Welfare League of America, '[a]pplicants should be accepted on the basis of an individual assessment of their capacity to understand and meet the needs of a particular available child at the point of the adoption and in the future." 287 Hopefully this will be one step closer to helping all children find stable homes and loving parents, like Annie found in Oliver Warbucks. $^{288}$

286. Mabry, supra note 64 , at 324.

287. Id. (citing from Child Welfare League of America, Standards of Excellence for Adoption Services, P 4.7 (2004)).

288. ANNIE, supra note 1. 